\title{
Genetic variants in mannose receptor gene (MRC1) confer susceptibility to increased risk of sarcoidosis
}

\author{
Takeshi Hattori ${ }^{1}$, Satoshi Konno ${ }^{1 *}$, Ayumu Takahashi ${ }^{1}$, Akira Isada ${ }^{1}$, Kaoruko Shimizu', Kenichi Shimizu', \\ Natsuko Taniguchi ${ }^{1}$, Peisong Gao ${ }^{2}$, Etsuro Yamaguchi ${ }^{3}$, Nobuyuki Hizawa ${ }^{4}$, Shau-Ku Huang ${ }^{2}$, Masaharu Nishimura ${ }^{1}$
}

\begin{abstract}
Background: Mannose receptor (MR) is a member of the C-type lectin receptor family involved in pathogen molecular-pattern recognition and thought to be critical in shaping host immune response. The aim of this study was to investigate potential associations of genetic variants in the MRC1 gene with sarcoidosis.

Methods: Nine single nucleotide polymorphisms (SNPs), encompassing the MRC1 gene, were genotyped in a total of 605 Japanese consisting of 181 sarcoidosis patients and 424 healthy controls.

Results: Suggestive evidence of association between rs691005 SNP and risk of sarcoidosis was observed independent of sex and age in a recessive model $(P=0.001)$.

Conclusions: These results suggest that MRC1 is an important candidate gene for sarcoidosis. This is the first study to imply that genetic variants in MRC1, a major member of the C-type lectin, contribute to the development of sarcoidosis.
\end{abstract}

\section{Background}

Sarcoidosis is a multi-organ inflammatory disease with exaggerated cellular immune activity that leads to formation of non-caseating granulomas in the affected organs. Although the causes of sarcoidosis remain unclear, several lines of evidence support the idea that sarcoidosis results from exposure of genetically susceptible individuals to unknown environmental triggers [1-9]. Amomg this evidence, environmental pathogens such as Mycobacterium and Propionibacterium species have been suggested to play roles in the pathogenesis of sarcoidosis [7-9]. Recent insights into the complex mechanisms underlying human innate immunity suggest that genetic variability in the genes encoding immune system components plays a role in the development of chronic inflammatory diseases. In particular, the association between sarcoidosis and genetic variants of several pattern recognition receptors (PRRs), such as Toll-like

\footnotetext{
* Correspondence: satkonno@med.hokudai.ac.jp

${ }^{1}$ First Department of Medicine, Hokkaido University School of Medicine, Sapporo, Hokkaido, Japan

Full list of author information is available at the end of the article
}

receptors (TLRs), have been extensively analyzed [10-12]. Although TLRs are an important system for microbial sensing, they are not the only PRRs with this function. At the cell-surface, C-type lectin-like molecules, such as the mannose receptor and the $\beta$-glucan receptors, also participate in the binding and uptake of microbial components $[13,14]$. Components of bacteria and viruses that gain entry into the cytoplasm are recognized by cytosolic receptors, through which they induce cytokine production and cell activation $[15,16]$. Recent studies have shown the genetic association between sarcoidosis and non-TLRs [11,17]. Mannose receptor (MR) is a member of the pattern-recognition C-type lectin receptor (CLR) family, which plays an important role in innate immunity. MR is predominantly present on macrophages and dendritic cells and recognizes glycan structures containing mannose, fucose and $\mathrm{N}$-acetylglucosamine, which are commonly found on the cell walls of pathogenic micro-organisms such as mycobacteria, fungus, parasites and yeast [18]. We therefore speculated that the $M R C 1$ gene may be an excellent candidate for susceptibility to sarcoidosis, and tested for associations 
between $M R C 1$ polymorphisms and the development of sarcoidosis in our Japanese case-control analysis.

\section{Methods \\ Subjects}

We enrolled unrelated subjects in this case-control study to search for susceptibility genes to sarcoidosis. A total of 181 Japanese subjects with sarcoidosis were recruited from the pulmonary clinic of the First Department of Medicine at Hokkaido University Hospital. Diagnosis of sarcoidosis in each patient was based on compatible clinical findings, histological demonstration of noncaseating epithelioid cell granuloma, and exclusion of other diseases capable of producing a similar histological or clinical picture, as recommended by the American Thoracic Society (ATS)/European Respiratory Society (ERS)/World Association of Sarcoidosis and Other Granulomatous Disorders (WASOG) statement. A total of 424 healthy controls, comprising individuals with no history of asthma or any other chronic pulmonary diseases, were recruited from individuals visiting the clinic for annual routine physical examinations and students at the School of Medicine at Hokkaido University. All subjects were unrelated and of Japanese descent. The medical ethics committee of Hokkaido University Graduate School of Medicine approved this study.

\section{SNP Selection and Genotyping}

Initially, we selected and genotyped seven SNPs in the MRC1 gene [12555A/G (rs2477637), 13789G/A (rs2253120), 17023A/C (rs2477631), 24351A/T (rs2477664), 31598A/G (rs692527), 40240G/A (rs1926736) and 111380T/C (rs691005)] based on our previous report [19]. As rs691005 showed a significant association, but major haplotyopes with strong linkage disequilibrium (LD) are not constructed by rs691005 using these 7 SNPs as described below (Figure 1), we genotyped two additional SNPs [11041G/A (rs554995) and 11065G/A (rs554313)] which are located close to rs691005. Additional LD structure using these 3 SNPs was shown in Figure 2. Alleles were identified using an assay combining kinetic (realtime quantitative) PCR with allele-specific amplification, as described elsewhere [19]. Real-time PCR was performed using SYBER Green I Master Mix (Applied Biosystems, Foster City, CA, USA) and an ABI PRISM TM 7700 Sequence Detection System (Applied Biosystems). Primers for allele specific PCR are shown in Table 1. rs554995 and rs554313 were genotyped using the TaqMan system (Applied Biosystems).

\section{Statistical Analysis}

Each of the SNPs in the MRC1 gene was tested for deviation from Hardy-Weinberg equilibrium using a $\chi^{2}$ test. Both genotypic and allelic association among

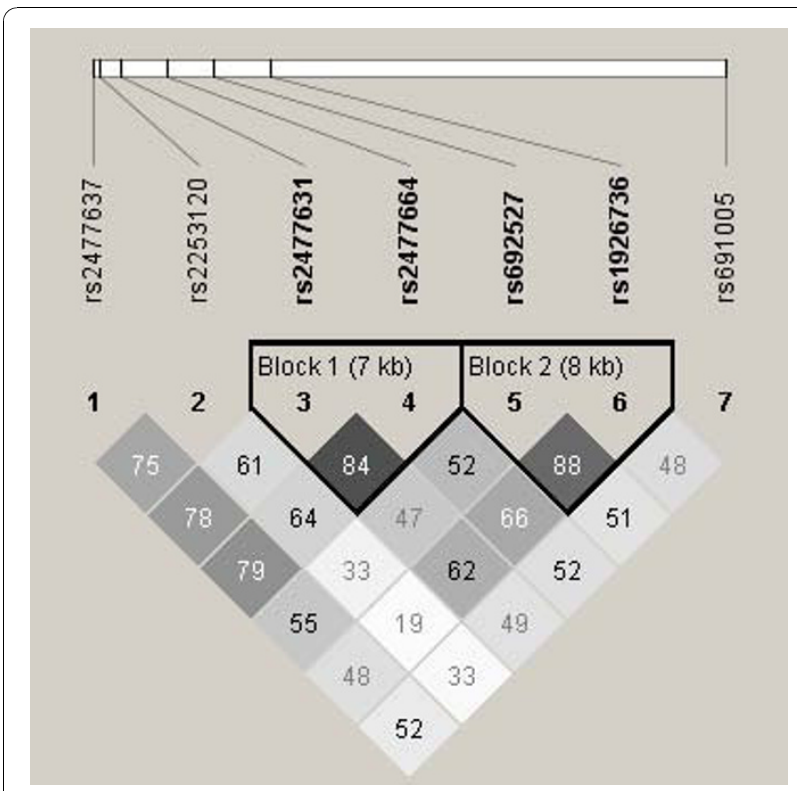

Figure 1 Linkage disequilibrium structure (LD) of $M R C 1$ gene across the $98.8 \mathrm{~kb}$ in Japanese $(n=605)$. Black squares represent high pairwise linkage disequilibrium, coloring down to white squares of low pairwise linkage disequilibrium. The numbers in the individual squares are D' multiplied by 100 .

subjects with sarcoidosis and healthy controls were statistically compared using the logistic regression analysis adjusting for sex and age. The relative risk was estimated as odds ratios (OR) with $95 \%$ confidence intervals (95\%CI). For LD mapping, pair-wise LD between polymorphisms in $M R C 1$ was evaluated using Haploview software version 4.2 [20]. For haplotype analyses, we used the haplo.score program, which calculates simulation $P$ values for each haplotype and further adjusts for covariates. Haplotypes with frequency below $5 \%$ were excluded from haplotype analysis. These statistical analyses were performed using a program $\mathrm{R}$ version 2.11.1 (http://www.R-project.org/) [21]. $P$ values were adjusted using the Bonferroni correction for 10 tests. Levels of significance for all statistical analyses were set to $P<$ 0.005 .

\section{Results}

Demographic characteristics of the 424 healthy controls and 181 subjects with sarcoidosis from this population are listed in Table 2. Median age was significantly higher for subjects with sarcoidosis than for healthy control subjects $(P<0.05)$. The sarcoidosis group included significantly more females than the control group $(P<$ 0.05). Pair-wise LD values for 7 SNPs are shown in Figure 1. No significant deviation from the Hardy-Weinberg equilibrium was observed in healthy control subjects $(P>0.05)$. Genotype and allele frequencies and 


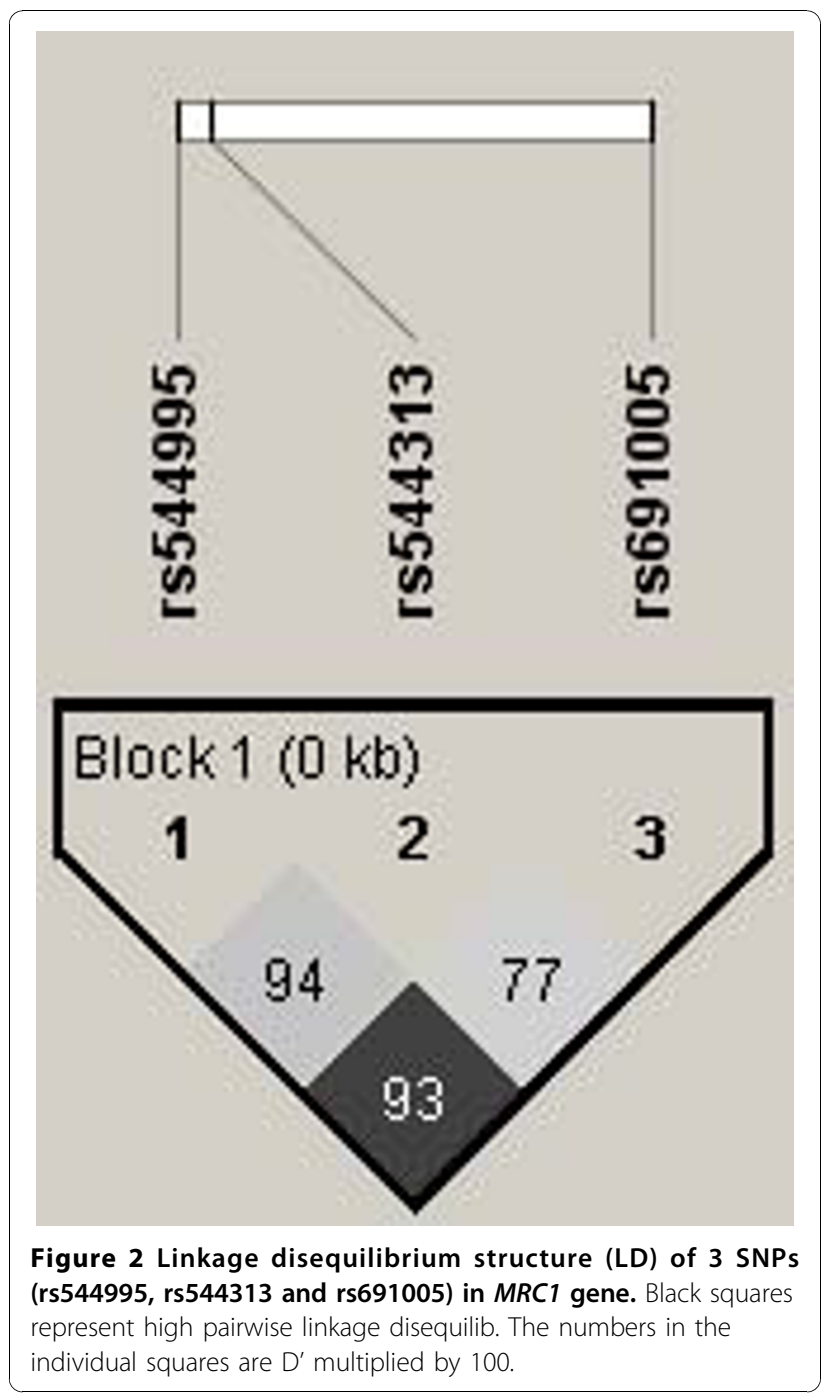

counts for each SNP in the $M R C 1$ gene are shown in Table 3. When we performed logistic repression analysis using a recessive model adjusted for age and gender, 3 SNPs tended to be associated with sarcoidosis (rs2477637, OR 1.76, 95\%CI, 1.09-2.84, $P=0.02$; rs692527, OR $1.58,95 \%$ CI $1.02-2.46, P=0.042$; and rs691005, OR 2.53, 95\%CI 1.47-4.37, $P=0.001$; Table 4). Additional association was observed for SNP rs2253120 (OR 1.62, 95\%CI 1.12-2.36, $P=0.011$ ), when analysis was performed under a dominant model. The rs691005 SNP remained statistically significant after Bonferroni correction. The linkage disequilibrium map constructed from 7 SNPs is shown in Figure 1, as measured by $\mathrm{D}$ prime and we identified two haplotype blocks. Haplotype block 1 comprised two SNPs (rs2477631 and rs2477664), and haplotype block 2 comprised two SNPs (rs692527 and rs1926736). However, significant association was not found in haplotype analysis (Table 5).
Table 1 Primers for allele specific PCR

\begin{tabular}{|c|c|c|}
\hline \multirow{2}{*}{$\frac{\text { Locus* }^{*}}{12555}$} & \multicolumn{2}{|r|}{ Primer sequence } \\
\hline & Forward & 5' ACTCAGTTACTTTCATTTGTTTATTCCTTAAC 3' \\
\hline & Reverse for $\mathrm{A}$ & 5' CCTTAAATTAAATCAAAATTGAGTTCAT 3' \\
\hline & Reverse for $G$ & 5' CCTTTAATTAAATCAAAATTGAGTTCAC 3' \\
\hline \multirow[t]{3}{*}{13789} & Forward & 5' GAATCTCAGATTATGAGTGTTGCATTा 3' \\
\hline & Reverse for $\mathrm{A}$ & 5' CATAGAGAGTGATAGCAACCCAGTCT 3' \\
\hline & Reverse for $G$ & 5' CATAGAGAGTGATAGCAACCCAGTCC $3^{\prime}$ \\
\hline \multirow[t]{3}{*}{17023} & Forward for $\mathrm{A}$ & 5' GGGATTGCAAGCGTGAGACA 3' \\
\hline & Forward for $\mathrm{C}$ & 5' GGGATTGCAAGCGTGAGACC 3' \\
\hline & Reverse & $5^{\prime}$ TाTGCAGATTCTACGACTTGAAAAAG 3' \\
\hline \multirow[t]{4}{*}{24351} & Forward for $\mathrm{A}$ & 5' GAGCTCCTGAGCATCACAGAGATA 3' \\
\hline & Forward for $T$ & 5' GAGCTCCTGAGCATCACAGAGATT 3' \\
\hline & Reverse for $\mathrm{A}$ & 5' ACTACCTGTCAGGTATGTTTGCTCAT 3' \\
\hline & Reverse for $\mathrm{T}$ & 5' CTTACCTGTCAGGTATGTTTGCTCAT 3' \\
\hline \multirow[t]{4}{*}{31598} & Forward for $\mathrm{A}$ & 5' CAATAAAGGTCTCTGTTTAAAGTTTCAA 3' \\
\hline & Forward for $\mathrm{G}$ & 5' CAATAAAGGTCTCTGTTTAAAGTTTCAG 3' \\
\hline & Reverse for $\mathrm{A}$ & 5' CAACACATCAGGGATACTCTGAGAAT 3' \\
\hline & Reverse for $\mathrm{G}$ & 5' GTACCCAACACATCAGGGATACTCT 3' \\
\hline \multirow[t]{3}{*}{40240} & Forward & $5^{\prime}$ AGGGATGCTCTGACCACCTG 3' \\
\hline & Reverse for $\mathrm{A}$ & 5' GTGTGGATACTTGCGAGGTCTCT 3' \\
\hline & Reverse for $G$ & $5^{\prime}$ TGTGGATACTTGGGAGGTCTCC $3^{\prime}$ \\
\hline \multirow[t]{4}{*}{111380} & Forward for $\mathrm{C}$ & 5' TCTCTITGGTACAACATAGTAAATCTCACC 3' \\
\hline & Forward for $\mathrm{T}$ & 5' TCTCTIITTGGTACAACATAGTAAATCTCACT 3 \\
\hline & Reverse for $C$ & $5^{\prime}$ TTACCAACTGTTTTCCCATAATTGTG 3' \\
\hline & Reverse for $T$ & 5' CCAACTGTTTTCCCATAATTGTGAG 3' \\
\hline
\end{tabular}

* Nucleotide numbering starts from the first nucleotide of the transcription start site.

Based on LD structure and significant association of rs691005 for initial analysis, we further genotyped two additional SNPs (rs554995 and rs554313) close to rs691005. Unfortunately, these two SNPs did not show significant associations (Tables 3 and 4). Although three SNPs (rs554995, rs554313 and rs691005) showed strong LD, significant associations were not found in haplotype analysis (Table 5).

\section{Discussion}

In the present study we demonstrated the association between $M R C 1$ polymorphisms and risk of sarcoidosis in Japanese population. In support of this, the association of

Table 2 Characteristics of 605 Japanese subjects

\begin{tabular}{lccc}
\hline Japanese population & $\begin{array}{c}\text { Control } \\
(\mathbf{n}=\mathbf{4 2 4})\end{array}$ & $\begin{array}{c}\text { Sarcoidosis } \\
(\mathbf{n}=\mathbf{1 8 1})\end{array}$ & $\begin{array}{c}\boldsymbol{P} \\
\text { value }\end{array}$ \\
\hline Male (\%)* & 65.3 & 30.9 & $<0.05$ \\
Age (median, range) $^{\dagger}$ & $38,18-72$ & $45,10-78$ & $<0.05$ \\
Stage (0/I/II/III/IV) & - & $21 / 90 / 59 / 11 / 0$ & \\
Occular lesion (\%) & - & 54.7 & \\
Cutaneous lesion (\%) & - & 17.7 & \\
Cardiac lesion (\%) & - & 7.2 &
\end{tabular}

$\overline{\text { Data are presented as median (interquartile range). }{ }^{*} \chi^{2} \text { test }+ \text { Mann-Whiteney }}$ $\mathrm{U}$ test. 
Table 3 Allele and genotype frequencies for 9 SNPs in MRC1 among subjects with sarcoidosis and control subjects

\begin{tabular}{|c|c|c|c|c|c|c|c|c|c|c|c|}
\hline SNP ID & Locus* & Role & AA change & Allele & Controls n (\%) & Cases n (\%) & $p^{\dagger}$ & Genotype & Controls n (\%) & Cases n (\%) & $P^{\neq}$ \\
\hline \multirow[t]{3}{*}{ rs2477637 } & 12555 & intron1 & none & $A$ & $547(64.5)$ & $213(58.8)$ & 0.062 & AA & $180(42.5)$ & $73(40.3)$ & 0.016 \\
\hline & & & & G & $301(35.5)$ & $149(41.2)$ & & $A G$ & $187(44.1)$ & $67(37.0)$ & \\
\hline & & & & & & & & GG & $57(13.4)$ & $41(22.7)$ & \\
\hline \multirow[t]{3}{*}{ rs2253120 } & 13789 & exon2 & none & G & $638(75.2)$ & $253(69.9)$ & 0.053 & GG & $250(59.0)$ & $86(47.5)$ & 0.016 \\
\hline & & & & A & $210(24.8)$ & $109(30.1)$ & & $A G$ & $138(32.5)$ & $81(44.8)$ & \\
\hline & & & & & & & & AA & $36(8.5)$ & $14(7.7)$ & \\
\hline \multirow[t]{3}{*}{ rs2477631 } & 17023 & intron2 & none & A & $443(52.2)$ & $191(52.8)$ & 0.868 & $\mathrm{AA}$ & $120(28.3)$ & $46(25.4)$ & 0.296 \\
\hline & & & & C & $405(47.8)$ & $171(47.2)$ & & $A C$ & $203(47.9)$ & $99(54.7)$ & \\
\hline & & & & & & & & $\mathrm{CC}$ & $101(23.8)$ & 36 (19.9) & \\
\hline \multirow[t]{3}{*}{ rs2477664 } & 24351 & exon4 & none & A & $455(53.7)$ & 191 (52.8) & 0.776 & $\mathrm{AA}$ & $131(30.9)$ & $49(27.1)$ & 0.412 \\
\hline & & & & $\mathrm{T}$ & $393(46.3)$ & $171(47.2)$ & & AT & $193(45.5)$ & $93(51.4)$ & \\
\hline & & & & & & & & $\Pi$ & $100(23.6)$ & $39(21.5)$ & \\
\hline \multirow[t]{3}{*}{ rs692527 } & 31598 & intron5 & none & A & $474(55.9)$ & $184(50.8)$ & 0.105 & $\mathrm{AA}$ & $130(30.7)$ & $50(27.6)$ & 0.145 \\
\hline & & & & G & $374(44.1)$ & $178(49.2)$ & & $A G$ & $214(50.5)$ & $84(46.4)$ & \\
\hline & & & & & & & & GG & $80(18.9)$ & $47(26.0)$ & \\
\hline \multirow[t]{3}{*}{ rs1926736 } & 40240 & exon7 & Gly/Ser & G & $443(52.2)$ & $198(54.7)$ & 0.433 & GG & $111(26.2)$ & $56(30.9)$ & 0.455 \\
\hline & & & & A & $405(47.8)$ & $164(45.3)$ & & $A G$ & $221(52.1)$ & $86(47.5)$ & \\
\hline & & & & & & & & $\mathrm{AA}$ & $92(21.7)$ & 39 (21.5) & \\
\hline \multirow[t]{3}{*}{ rs544995 } & 111041 & $3^{\prime}-$ UTR & none & G & $598(70.5)$ & $254(70.2)$ & 0.957 & GG & $200(47.2)$ & 88 (48.6) & 0.526 \\
\hline & & & & A & $250(29.5)$ & $108(29.8)$ & & $A G$ & $198(46.7)$ & $78(43.1)$ & \\
\hline & & & & & & & & $\mathrm{AA}$ & $26(6.1)$ & $15(8.3)$ & \\
\hline \multirow[t]{3}{*}{ rs544995 } & 111065 & 3'-UTR & none & G & $522(63.4)$ & $239(66.0)$ & 0.159 & GG & $163(38.4)$ & 75 (41.4) & 0.148 \\
\hline & & & & A & 326 (39.6) & $123(34.0)$ & & $A G$ & $196(46.2)$ & $89(49.2)$ & \\
\hline & & & & & & & & AA & 65 (15.3) & $17(9.4)$ & \\
\hline \multirow[t]{3}{*}{ rs691005 } & 111380 & $3^{\prime}-U T R$ & none & $\mathrm{T}$ & $576(67.9)$ & $226(62.4)$ & 0.064 & $\Pi$ & $191(45.0)$ & 79 (43.6) & 0.003 \\
\hline & & & & $C$ & $272(32.1)$ & 136 (37.6) & & $\mathrm{TC}$ & $194(45.8)$ & 68 (37.6) & \\
\hline & & & & & & & & CC & 39 (9.2) & 34 (18.8) & \\
\hline
\end{tabular}

* Nucleotide numbering starts from the first nucleotide of the transcription start site.

† Allele frequencies of each SNP were compared between sarcoidosis and controls by $\chi 2$ test $(2 \times 2)$.

‡ Overall genotype differeneces were compared between sarcoidosis and controls by $\chi 2$ test $(2 \times 3)$.

one SNP (rs691005) was confirmed considering for multiple testing and Bonferroni correction, suggesting $M R C 1$ gene as a plausible candidate gene for development of sarcoidosis. Of interest, recent genome-wide association

Table 4 Odds ratios (OR) and $P$ values for 9 SNPs in MRC1 among subjects with sarcoidosis and control subjects

\begin{tabular}{lcccc}
\hline & \multicolumn{2}{c}{ Dominant model } & \multicolumn{2}{c}{ Recessive model } \\
& OR [95\% CI] & $P$ value* $^{*}$ & OR [95\% CI] & $\boldsymbol{P}^{\text {value* }}$ \\
\hline rs2477637 & $1.04[0.71-1.52]$ & 0.843 & $1.76[1.09-2.84]$ & 0.02 \\
rs2253120 & $1.62[1.12-2.36]$ & 0.011 & $0.83[0.42-1.65]$ & 0.593 \\
rs2477631 & $1.08[0.70-1.64]$ & 0.739 & $0.79[0.50-1.24]$ & 0.298 \\
rs2477664 & $1.18[0.78-1.78]$ & 0.433 & $0.87[0.56-1.36]$ & 0.535 \\
rs692527 & $1.15[0.76-1.74]$ & 0.496 & $1.58[1.02-2.46]$ & 0.042 \\
rs1926736 & $0.78[0.52-1.17]$ & 0.222 & $0.97[0.62-1.53]$ & 0.906 \\
rs554995 & $0.90[0.62-1.31]$ & 0.588 & $1.43[0.70-2.95]$ & 0.326 \\
rs554313 & $0.83[0.57-1.21]$ & 0.336 & $0.65[0.36-1.18]$ & 0.159 \\
rs691005 & $1.00[0.69-1.46]$ & 0.987 & $2.53[1.47-4.37]$ & 0.001 \\
\hline
\end{tabular}

* logistic regression model: adjusted by sex and age. analyses have shown that $10 \mathrm{p} 12$, where $M R C 1$ is situated, is a susceptibility locus for the development of sarcoidosis [22]. Thus, findings of the current study suggest that $M R C 1$ gene variants may contribute to the development of sarcoidosis.

The rs691005 located within the 3'-untranslated region (3'-UTR) of MRC1 showed the strongest association (OR 2.53). Although the real functions of this gene are unclear, variants in the 3'-UTR are known to disrupt a regulatory binding sequence and alter mRNA expression [23]. Alternatively, this variant may be representative of the region or correlated with a true functional variant. Thus, our current results provide a basis for further identification of the causative variants underlying the relationship between $M R C 1$ gene sequences and sarcoidosis.

It should be noted that SNPs with two positions were mapped to MRC1 spanning chr10:17,891,368-17,993,183 (HapMap Data Rel 27) and were referred to by their MRC1L1 'rs'numbers (NCBI EntrezSNP database Build 130). Alter et al reported no evidence for a common 
Table 5 Estimated haplotype frequencies and association with sarcoidosis

\begin{tabular}{|c|c|c|c|c|c|}
\hline Haplotype & controls $(\%)^{*}$ & cases $(\%)^{*}$ & total $(\%)^{*}$ & haplotype-specific score & simulated $P^{\dagger}$ \\
\hline \multicolumn{6}{|c|}{ rs2477631-rs2477664 } \\
\hline$A-A$ & 48.6 & 48.4 & 48.6 & -0.171 & 0.863 \\
\hline$C-T$ & 42.7 & 42.9 & 42.8 & 0.089 & 0.929 \\
\hline \multicolumn{6}{|c|}{ rs692527-rs1926736 } \\
\hline$A-A$ & 46.0 & 41.4 & 44.6 & -1.601 & 0.111 \\
\hline$A-G$ & 9.8 & 9.5 & 9.7 & -0.428 & 0.667 \\
\hline G-G & 42.4 & 45.2 & 43.2 & 1.074 & 0.279 \\
\hline \multicolumn{6}{|c|}{ rs554995-rs554313-rs691005 } \\
\hline G-G-T & 30.6 & 30.6 & 30.6 & 0.098 & 0.916 \\
\hline$A-G-C$ & 27.7 & 29.4 & 28.1 & 0.741 & 0.452 \\
\hline G-A-T & 29.3 & 36.2 & 34.7 & 2.220 & 0.028 \\
\hline
\end{tabular}

*Minimum haplortpe frequency was 0.05 for which haplotypes were scored in the model.

tadjusted by sex and age.

gene duplication event [24]. The authors suggested that $M R C 1 L$ is an erroneous annotation caused by the presence of a sequence gap and the incorrect assignment of a polymorphic haplotype.

We also reported the association of $M R C 1$ gene polymorphism and risk of asthma in two independent ethnically diverse populations [19], suggesting that $M R C 1$ might be involved in the pathogenesis of a number of chronic inflammatory diseases. Several reports have shown that genetic variants of genes related to PRRs such as TLR4 and CD14 are associated with susceptibility to both diseases $[10,11,25-27]$. The present study adds further evidence supporting the involvement of macrophage PRRs in the development of sarcoidosis as a chronic inflammatory lung disease.

Of the SNPs examined, three SNPs (rs26777637, rs2253120 and rs692427) showed tendency for association with sarcoidosis $(P=0.02, P=0.011, P=0.042)$, but this association did not reach significance after the Bonferroni correction. However, associations of rs691005 remained significant even after Bonferroni correction $(P=0.001)$. In addition, power calculations based on study subjects of 181 cases and 424 controls, OR of 2.53 showed a sufficient genetic power (0.81) at the level of significance of 0.005 . As the sample size of this study is not sufficiently large and is restricted to Japanese population, the present data should be validated in larger samples and in other ethnic groups.

\section{Conclusions}

This study suggests that the $M R C 1$ gene may represent an important susceptibility locus for sarcoidosis at chromosome 10p12 and genetic variants in MRC1 may play significant roles in the pathogenesis of sarcoidosis. Importantly, the association we observed between MRC1 polymorphisms and sarcoidosis adds further evidence for the involvement of macrophage PRRs in the development of a number of chronic inflammatory diseases, including sarcoidosis. However, further studies are clearly needed to achieve a comprehensive coverage of genetic variants in and around the $M R C 1$ gene, in order to identify causal variants conferring susceptibility to an increased risk of sarcoidosis.

\section{Acknowledgements}

We gratefully acknowledge the numerous sample donors for making this work possible.

\section{Author details}

${ }^{1}$ First Department of Medicine, Hokkaido University School of Medicine, Sapporo, Hokkaido, Japan. ${ }^{2} J o h n s$ Hopkins Asthma \& Allergy Center, Johns Hopkins University School of Medicine, Baltimore, MD, USA. ${ }^{3}$ Division of Respiratory Medicine and Allergology, Aichi Medical University, Aichi, Japan. ${ }^{4}$ Department of Pulmonary Medicine, Institute of Clinical Medicine, Graduate School of Comprehensive Human Sciences and University Hospital,

University of Tsukuba, Tsukuba, Ibaraki, Japan.

\section{Authors' contributions}

The authors $\mathrm{TH}, \mathrm{SK}, \mathrm{PG}, \mathrm{SH}, \mathrm{NH}$ and $\mathrm{MN}$ made substantial contribution to the conception and design of the study, and analysis and interpretation of the data. AT, Al, Kaouruko S, Kenichi S, and NT, and EY made a substantial contribution to the collection of the resources and an intellectual contribution to the study design. All authors read and approved the final version.

\section{Competing interests}

The authors declare that they have no competing interests.

Received: 29 March 2010 Accepted: 28 October 2010 Published: 28 October 2010

\section{References}

1. Newman LS, Rose CS, Bresnitz EA, Rossman MD, Barnard J, Frederick M, Terrin ML, Weinberger SE, Moller DR, McLennan G, Hunninghake G, DePalo L, Baughman RP, lannuzzi MC, Judson MA, Knatterud GL, Thompson BW, Teirstein AS, Yeager H Jr, Johns CJ, Rabin DL, Rybicki BA, Cherniack R, ACCESS Research Group: A case control etiologic study of sarcoidosis: environmental and occupational risk factors. Am J Respir Crit Care Med 2004, 170:1324-1330.

2. Kucera GP, Rybicki BA, Kirkey KL, Coon SW, Major ML, Maliarik MJ, lannuzzi MC: Occupational risk factors for sarcoidosis in African-American siblings. Chest 2003, 123:1527-1535. 
3. Prezant DJ, Dhala A, Goldstein A, Janus D, Ortiz F, Aldrich TK, Kelly KJ: The incidence, prevalence, and severity of sarcoidosis in New York City firefighters. Chest 1999, 116:1183-1193.

4. Rybicki BA, lannuzzi MC, Frederick MM, Thompson BW, Rossman MD, Bresnitz EA, Terrin ML, Moller DR, Barnard J, Baughman RP, DePalo L, Hunninghake G, Johns C, Judson MA, Knatterud GL, McLennan G, Newman LS, Rabin DL, Rose C, Teirstein AS, Weinberger SE, Yeager $\mathrm{H}$, Cherniack R: ACCESS Research Group Familial aggregation of sarcoidosis: A Case-Control Etiologic Study of Sarcoidosis (ACCESS). Am J Respir Crit Care Med 2001, 164:2085-2091.

5. Rossman MD, Thompson B, Frederick M, Maliarik M, lannuzzi MC, Rybicki BA, Pandey JP, Newman LS, Magira E, Beznik-Cizman B, Monos D, ACCESS Group: HLA-DRB1*1101: a significant risk factor for sarcoidosis in blacks and whites. Am J Hum Genet 2003, 73:720-735.

6. Valentonyte R, Hampe J, Huse K, Rosenstiel P, Albrecht M, Stenzel A, Nagy M, Gaede Kl, Franke A, Haesler R, Koch A, Lengauer T, Seegert D, Reiling N, Ehlers S, Schwinger E, Platzer M, Krawczak M, Müller-Quernheim J, Schürmann M, Schreiber S: Sarcoidosis is associated with a truncating splice site mutation in BTNL2. Nat Genet 2005, 37:357-364.

7. Eishi Y, Suga M, Ishige I, Kobayashi D, Yamada T, Takemura T, Takizawa T, Koike M, Kudoh S, Costabel U, Guzman J, Rizzato G, Gambacorta M, du Bois R, Nicholson AG, Sharma OP, Ando M: Quantitative analysis of mycobacterial and propionibacterial DNA in lymph nodes of Japanese and European patients with sarcoidosis. J Clin Microbiol 2002, 40:198-204.

8. Song Z, Marzilli L, Greenlee BM, Chen ES, Silver RF, Askin FB, Teirstein AS, Zhang Y, Cotter RJ, Moller DR: Mycobacterial catalase-peroxidase is a tissue antigen and target of the adaptive immune response in systemic sarcoidosis. J Exp Med 2005, 201:755-767.

9. Hajizadeh R, Sato H, Carlisle J, Nadaf MT, Evans W, Shepherd BE, Miller RF, Kalams SA, Drake WP: Mycobacterium tuberculosis antigen 85A induces Th-1 immune responses in systemic sarcoidosis. J Clin Immunol 2007, 27:445-454.

10. Pabst S, Baumgarten $G$, Stremmel A, Lennarz M, Knüfermann P, Gillissen A, Vetter $\mathrm{H}$, Grohé C: Toll-like receptor (TLR) 4 polymorphisms are associated with a chronic course of sarcoidosis. Clin Exp Immunol 2006, 143:420-426.

11. Gazouli M, Koundourakis A, Ikonomopoulos J, Gialafos EJ, Rapti A, Gorgoulis VG, Kittas C: CARD15/NOD2, CD14, and toll-like receptor 4 gene polymorphisms in Greek patients with sarcoidosis. Sarcoidosis Vasc Diffuse Lung Dis 2006, 23:23-29.

12. Veltkamp M, Wijnen PA, van Moorsel CH, Rijkers GT, Ruven HJ, Heron M, Bekers O, Claessen AM, Drent M, van den Bosch JM, Grutters JC: Linkage between Toll-like receptor (TLR) 2 promotor and intron polymorphisms: functional effects and relevance to sarcoidosis. Clin Exp Immunol 2007, 149:453-462

13. McGreal EP, Miller JL, Gordon S: Ligand recognition by antigen-presenting cell C-type lectin receptors. Curr Opin Immunol 2005, 17:18-24.

14. Brown GD: Dectin-1: a signalling non-TLR pattern recognition receptor. Nature Rev Immunol 2006, 6:33-43.

15. Akira S, Uematsu S, Takeuchi O: Pathogen recognition and innate immunity. Cell 2006, 124:783-801.

16. Fritz JH, Girardin SE: How Toll-like receptors and Nod-like receptors contribute to innate immunity in mammals. J Endotoxin Res 2005, 11:390-394.

17. Sato H, Williams HR, Spagnolo P, Abdallah A, Ahmad T, Orchard TR, Copley SJ, Desai SR, Wells AU, du Bois RM, Welsh KI: CARD15/NOD2 polymorphisms are associated with severe pulmonary sarcoidosis. Eur Respir J 2010, 35:324-330.

18. East L, Isacke CM: The mannose receptor family. Biochim Biophys Acta 2002, 1572:364-386.

19. Hattori T, Konno S, Hizawa N, Isada A, Takahashi A, Shimizu K, Shimizu K, Gao P, Beaty TH, Barnes KC, Huang SK, Nishimura M: Genetic variants in the mannose receptor gene (MRC1) are associated with asthma in two independent populations. Immunogenetics 2009, 61:731-738.

20. Barrett JC, Fry B, Maller J, Daly MJ: Haploview: analysis and visualization of LD and haplotype maps. Bioinformatics 2005, 21:263-265.

21. Ihaka $R, R$ Gentleman $R$ : a language for data analysis and graphics. $J$ Comp Graph Stat 1996, 5:299-314.

22. Franke A, Fischer A, Nothnagel M, Becker C, Grabe N, Till A, Lu T, MüllerQuernheim J, Wittig M, Hermann A, Balschun T, Hofmann S, Niemiec R, Schulz S, Hampe J, Nikolaus S, Nürnberg P, Krawczak M, Schürmann M,
Rosenstiel P, Nebel A, Schreiber S: Genome-wide association analysis in sarcoidosis and Crohn's disease unravels a common susceptibility locus on 10p12.2. Gastroenterology 2008, 135:1207-1215.

23. Huang JL, Gao PS, Mathias RA, Yao TC, Chen LC, Kuo ML, Hsu SC, Plunkett B, Togias A, Barnes KC, Stellato C, Beaty TH, Huang SK: Sequence variants of the gene encoding chemoattractant receptor expressed on Th2 cells (CRTH2) are associated with asthma and differentially influence mRNA stability. Hum Mol Genet 2004, 13:2691-2697.

24. Alter A, de Léséleuc L, Van Thuc N, Thai VH, Huong NT, Ba NN, Cardoso CC, Grant AV, Abel L, Moraes MO, Alcaïs A, Schurr E: Genetic and functional analysis of common MRC1 exon 7 polymorphisms in leprosy susceptibility. Hum Genet 2010, 127:337-48.

25. Koppelman GH, Reijmerink NE, Colin Stine O, Howard TD, Whittaker PA, Meyers DA, Postma DS, Bleecker ER: Association of a Promoter Polymorphism of the CD14 Gene and Atopy. Am J Respir Crit Care Med 2001, 163:965-969.

26. Arbour NC, Lorenz E, Schutte BC, Zabner J, Kline JN, Jones M, Frees K, Watt $J$, Schwartz DA: TLR4 mutations are associated with endotoxin hyporesponsiveness in humans. Nat Genet 2000, 25:187-191.

27. Fagerås Böttcher $M, H$ mani-Aifa $M$, Lindström $A$, Jenmalm MC, Mai XM, Nilsson L, Zdolsek HA, Björkstén B, Söderkvist P, Vaarala O: A TLR4 polymorphism is associated with asthma and reduced lipopolysaccharide-induced interleukin-12(p70) responses in Swedish children. J Allergy Clin Immunol 2004, 114:561-756.

\section{Pre-publication history}

The pre-publication history for this paper can be accessed here: http://www.biomedcentral.com/1471-2350/11/151/prepub

doi:10.1186/1471-2350-11-151

Cite this article as: Hattori et al:: Genetic variants in mannose receptor gene (MRC1) confer susceptibility to increased risk of sarcoidosis. BMC Medical Genetics 2010 11:151.

\section{Submit your next manuscript to BioMed Central and take full advantage of:}

- Convenient online submission

- Thorough peer review

- No space constraints or color figure charges

- Immediate publication on acceptance

- Inclusion in PubMed, CAS, Scopus and Google Scholar

- Research which is freely available for redistribution

Submit your manuscript at www.biomedcentral.com/submit
C Biomed Central 